\title{
Do Board Gender Diversity and Non-Executive Directors Affect CSR Reporting? Insight from Agency Theory Perspective
}

\author{
Cheng Guping ${ }^{1}$, Muhammad Safdar Sial ${ }^{2}$, Peng Wan ${ }^{3, * \mathbb{C}}$, Alina Badulescu ${ }^{4} \mathbb{C}^{\text {, }}$ \\ Daniel Badulescu ${ }^{4}$ (D) and Talles Vianna Brugni ${ }^{5}$ (D) \\ 1 Economics and Management School, Wuhan University, Wuhan 430072, China; 2016101050114@whu.edu.cn \\ 2 Department of Management Sciences, COMSATS University Islamabad (CUI), Islamabad 44000, Pakistan; \\ safdar.sial786@gmail.com \\ 3 School of Accounting, Zhejiang Gongshang University, Hangzhou 310018, China \\ 4 Department of Economics and Business, Faculty of Economic Sciences, University of Oradea, \\ 410087 Oradea, Romania; abadulescu@uoradea.ro (A.B.); dbadulescu@uoradea.ro (D.B.) \\ 5 Accounting Department, FUCAPE Business School, Av. Fernando Ferrari, 1358, Boa Vista, \\ Vitória-ES 29075-505, Brazil; tallesbrugni@fucape.br \\ * Correspondence: wanpeng@zjsu.edu.cn
}

Received: 10 August 2020; Accepted: 15 October 2020; Published: 16 October 2020

\begin{abstract}
Our paper provides a valuable contribution by exploring the following complex phenomenon: Do board gender diversity and reputational incentives of non-executive directors affect corporate social responsibility(CSR) reporting? To this end, we use panel data regression (fixed effect) to examine the above relationship by using data from the 2009 to 2019 timeperiod, by using data from non-financial firms listed on the Shanghai Stock Exchange. To deal with the possibility of an endogeneity problem, we have used the two-stage least square (2SLS) regression model. Our empirical results suggest that board gender diversity positively affects CSR reporting. Our study has found that the reputational incentives of non-executive directors improve the CSR reporting. Furthermore, reputational incentives of non-executive directors (NEDs) and CSR reporting are moderated by firm size, this effect being stronger for large firms. Our findings also show that the firm size positively moderates the relationship between gender diversity in boards and CSR reporting. The control variables, namely board size, board member average tenure, leverage, "big 4" and return on assets, have an impact on the firm's CSR reporting. Therefore, our results contribute towards new aspects in respect to the emerging literature concerning the system of non-executive directors, protection of stakeholder's interests, and CSR reporting, especially as regards China. Furthermore, our results are robust as concerns alternative measures of variables under consideration.
\end{abstract}

Keywords: board gender diversity; non-executive directors; reputational incentives; CSR reporting; corporate governance; Chinese firms

\section{Introduction}

Currently, and from an organizational point of view, Corporate Social Responsibility (CSR) has gained more importance, as it is considered as a source of competitive advantage [1]. Therefore, a larger number of companies have an increasing interest in CSR and engage themselves in various CSR activities [2]. How to implement CSR is an important task, which is applicable and relevant for every firm.

The main aim of this study is to contribute to the existing literature on CSR reporting by examining whether the gender diversity in boards and non-executive directors' reputational incentives influence 
the CSR reporting of Chinese firms. The main motivational factor behind board members' gender diversity and the non-executive directors' reputational incentives is to promote CSR activities. In this regard, Fama [3] argues that the main incentive for such directors is the reputation that they would gain from supporting and implementing such CSR activities, because an increase in reputation would raise the power and influence within the board of the company in which they operate; what is more, CSR activities would also result in enhanced career opportunities, together with other future beneficial prospects as well [4]. Corporate governance, social issues, and CSR-related problems are now crucial dimensions of an organization's overall activity. However, the existing research related to corporate governance (board gender diversity and non-executive directors' reputational incentives) and CSR reporting is still very limited and is only related to already developed markets $[5,6]$.

According to their "business case for diversity", Robinson and Dechant [7] claim that women board members of companies are believed to be a true and significant value generator for corporations and stakeholders, especially given the pressure coming from stock markets and numerous shareholders, which have demanded more transparency as concerns CSR reporting [8]. What is more, the European Commission, in 2001, has developed a CSR management business case, detailing in it how "corporations make it-CSR-part of the concerns related to society and environment in its regular operations and its voluntarily dealing with stakeholders". Therefore, it created emerging responsibilities on directors, such as the collective domain of corporate functions and related accountability, supporting the possibility of a relationship between women directors of the board and the corporation's CSR reporting.

Cho and Patten [9] have studied the determining factors that lead to both social and CSR disclosures. They have found that CSR disclosures are usually used as a tool by corporate groups in order to legitimize their actions. Patten [10] has also studied the relationship between the performance of the CSR dimension of corporations and their disclosures. In the same time, it is important to mention that such studies did not find any relationship between the concerned variables. Furthermore, other studies, for instance [11], analyse the effects that corporate governance mechanisms have upon on the overall environmental and CSR related disclosures. The research has showed that corporate governance has a significant duty to play in CSR and disclosures related to the sustainability of US and European companies.

According to Terjesen and Couto [12], the literature related to board gender diversity is only focused on the underrepresentation of female directors at various levels. Furthermore, according to Galbreath and Shum [13], the literature on governance, social responsibility, and CSR studies are limited and largely focused only on finding the relationship between governance, social responsibility and CSR, and companies' financial performance. Additionally, these studies have only tried to conduct research on CSR and companies' performance, ignoring the role of corporate governance systems, hence missing out on one important research dimension.

According to Fernández-Gago and Cabeza-García [14], the presence of non-executive directors tends to improve the implementation of CSR, whilst also protecting interests of different stakeholders. This has led to changes being made as regards corporate regulations in many countries, making it mandatory to have non-executive directors in the board of directors [15]. Even though the main objective of such regulations is to protect the rights of different stakeholders, at the same time, there seems to be no universal consensus in specialty literature on whether these objectives for the presence of non-executive directors are ever fulfilled. According to Wang and Jin [16], the presence of non-executive directors does not improve the corporate governance performance of firms [16]. On the other hand, Chen and Dyball [17] found that their presence improved the accounting and the quality of corporate reporting in general [18]. Liu and Wang [19] argue that the presence of non-executive directors in the board of directors leads to a reduction of tunneling issues of firms.

Cavaco and Crifo [20] state that the results of empirical research on the impact of non-executive directors on firm's performance are mixed, and therefore their impact cannot accurately be measured. Given this, the effectiveness of independent directors in CSR remains unclear and needs further 
investigation. The lack of consensus on the positive impact that non-executive directors have upon the improvement of CSR reporting and performance is largely related to the motivations behind such directors, and these aspects remain mostly unknown.

According to Fama and Jensen [21], the motivational aspect can be attributed to reputational incentives [3], as good corporate reputation not only increases the influence of directors in the firm, but it also expands their career opportunities [22].

Past studies checked the effect of non-executive directors on CSR reporting, but did not consider the reputational incentive of non-executive directors. In this regard, we bridge this gap by assessing the impact of non-executive directors reputational incentives on CSR reporting improvements, along with the protection of the interests of various stakeholders. We anticipate a positive impact of non-executive directors upon CSR reporting, given their positive reputation. Even though legal corporate structure in China is considered as being weak, the reward mechanism for such directors is important and quite high. Future opportunities for the Chinese corporate sector are quite numerous and are well suited. The reasons behind this statement shall be presented in the following paragraphs.

Firstly, non-executive directors occupy multiple positions. In 2009, almost $75 \%$ of the non-executive directors of the boards of directors were occupying multiple tenures. In this sense, Brickley et al. [23] analyzed whether they were able to achieve their responsibilities. As it is commonly associated with a professional with a high reputation, it is expected that such professionals should have multiple tenures. In this regard, multiple tenures are favored by the corporate job market in China [24].

Secondly, the main reason, which is a unique characteristic specific to the Chinese corporate sector, lies in the weakness regarding regulations that protect stakeholders and minority shareholders. In most cases, the ownership is concentrated in a few hands, and may also belong to the same family group. In such cases, the owners also serve as directors. This reduces the chances of shareholders' pressure and creates issues of "tunneling", given that these directors tend to pursue their private interests at the cost of shareholders. This issue is becoming more severe as time passes. Wang and Chen [25] state that this has also led to the deterioration of the CSR reporting of Chinese listed companies [26]. To protect the interests of such stakeholders, the Chinese government has introduced regulations related to the supervisory board, which must consist of non-executive directors. These directors have to be appointed from outside the companies, so that their independence is not compromised [27]. The guidelines issued in this regard by the China Securities Regulatory Commission clearly state that these directors must maintain their independence from the influence of majority shareholding groups in letter and spirit [28]. Such actions initially led to high hopes that these directors will be able to provide protection to minority shareholders and resolve the issues of tunneling of self-interest by directors [15]. The main objective of the Chinese system was to resolve the issues mentioned above, unlike the system of non-executive directors in countries such the USA, where the main objective is to resolve agency issues.

Thirdly, we highlight some of the main potential reasons why the impact of board gender diversity on corporate social responsibility (CSR) reporting is moderated by firm size: (i) Larger firms tend to have more financial resources than smaller firms [11]. In this regard, larger firms are expected to invest in projects to better manage their relationships with stakeholders and hence to reach legitimacy and credibility, such as CSR. In contrast, smaller firms tend to use their financial resources to improve performance in their businesses through more traditional strategies, especially those financially constrained; (ii) considering that CSR initiatives tend not to be functional in small structures and on a smaller scale, they tend to require better-elaborated processes to be effective [14]. In this regard, firm size is a critical factor to make CSR processes effective. Another reason for firm size moderating the impact of board gender diversity on CSR reporting is economies of scale, as it contributes to enhancing corporate social performance (CSP). Thus, resource availability and corporate social responsibility processes are likely to be found in large firms, because CSR requires a high number of people involved in such activities to facilitate improved social responsiveness (Donaldson, 2001); (iii) according to Michelon [11], the academic literature suggests that company visibility is important to involving larger 
and diverse groups of stakeholders; and (iv) large companies tend to have more capacity to implement complex processes, i.e., CSR projects because they tend to have more well-defined goals, measures, and procedures to monitor their activities.

This study makes several contributions to literature related to CSR. First, we add to the existing set of literature by proving the Chinese perspective as regards CSR reporting. Corporate social responsibility has become a very important issue in the Chinese corporate sector [29]. In this regard, our analysis incorporates the impact of board gender diversity and the reputational incentives of non-executive directors on CSR reporting in Chinese firms. The Chinese corporate environment is unique and has both influenced and been influenced by distinctive political and social characteristics.

Secondly, the present research provides strong evidence in favor of reputational incentives as a motivational factor for non-executive directors. Previous studies such as Cheng [30] and Hussain and Rigoni [31], have stated that some factors such as social connections, individual personality, and amount of compensation of non-executive directors can also have an impact on their ability to fully execute their duties. But in recent times, researchers have focused on the reputational incentives as the main motivator for them to fully execute their role [32]. At the same time, to the best of our knowledge, the effect of reputational incentives of non-executive directors on CSR reporting is very limited. In this respect, our findings point towards reputational incentives as being the main motivator for non-executive directors to execute their supervisory and advisory roles. Our research adds to the existing body of literature and extends the contribution towards non-executive directors perspective.

Thirdly, we have analyzed the effects of reputational incentives of non-executive directors in different scenarios, depending on firms' characteristics. Previous studies have not considered the moderating effect of firm size in this context. Therefore, we have added firm size as a moderator variable between reputational incentives of non-executive directors and gender diversity in boards with CSR reporting. Our study not only shows the effect of reputational incentives of non-executive directors, but it also shows that this effect is different based on firm size, thus making unique contributions to existing literature.

Finally, most of the past studies are conducted in the context of developed economies [32], while the present study focuses entirely on the Chinese context, which largely remains unexplored as regards reputational incentives of non-executive directors and CSR reporting. Many of the characteristics of the Chinese market are common among other developing markets, thus, the results of our study will also be related to emerging markets.

Our results show that the gender diversity of boards of directors has a significantly positive effect on CSR reporting. Our results also indicate a positive impact of reputational incentives of non-executive directors on the improvement of CSR and on the protection of the stakeholders' and shareholders' interests. The impact level is much stronger in large organizations as compared to small and medium-sized organizations. In this respect, our findings indicate that reputational incentive is indeed a strong motivational factor for non-executive directors for the fulfilment of their monitoring and advisory role, especially when it comes to large organizations. Our findings also show that the firm size positively moderates the relationship between gender diversity in boards of directors and CSR reporting. This means that big firms are more socially responsible while employing CSR reporting, as compared to smaller firms, given that big firms are associated with slack-financial resources as compared to smaller firms, and this significantly affects CSR reporting.

Regarding the control variables (board size, leverage, board member average tenure, big 4, and return on asset), we can state that they are associated with CSR reporting, confirming the previous findings by existing literature. Therefore, we add to the literature on CSR reporting by giving some empirical evidence regarding board gender diversity and reputational incentives of non-executive directors as being a very crucial corporate governance aspect; what is more, we also provide evidence as regards the extent of CSR reporting in the context of developing economies.

The rest of the paper is organized as follows: Section 2 represents the institutional background; Section 3 represents the theoretical framework, literature review, and research hypotheses; Section 4 
describes the research methods and findings; Section 5 describes the empirical results and discussion; and finally, Section 6 concludes with implications for future research.

\section{Institutional Background}

The Chinese investors have long since demanded transparency in corporate governance structures and decision making in the board of directors to protect their investments. Many academics and researchers in the past, such as $[33,34]$, have criticized the Chinese corporate structure because of their lack of transparency and effectiveness of the boards. As a result, the Chinese Securities Regulatory Commission (CSRC) incorporated many changes in the corporate governance regulations, which include the Code of Corporate Governance of China (2001), Advisory for Institution of Independent Directors (2001), and Disclosure Requirements for Companies (2007). The guidelines and definitions of the roles and duties of directors are almost the same as the Anglo-Saxon model.

The absence of female directors has motivated regulators and policy makers to introduce gender quotas in many countries. According Sial and Chunmei [35], European Union commission support the encouragement of female presence in top management positions and accepted the suggestion on equality of gender quotas on supervisory boards. Consequently, 40 percent of the seats in the board must be occupied by the female minority by 2010 . However, we did not see such quotas in China.

One of the most researched topics in China is the structure of the board of directors and its impact on corporate performance. According to Wang and Yao [36], who analyzed 30 studies, 63\% reported positive, $30 \%$ negative, and $7 \%$ reported an insignificant impact of the structure of the board of directors on the corporate performance of listed Chinese companies. The main contributing factor in this regard is the fact that Chinese corporate regulations have been continuously evolving since the year 2000 [37]. This has also posed a challenge for researchers, as with every change, it became ever more difficult to analyze the impact of board structure with every passing period. Many changes were preceeded by changes in the requirements of Non-executive directors. The second issue is related to the ownership structure of Chinese companies in different industrial sectors. When conducting cross-sectional studies, the majority of the organizations were state-owned, but now this trend is declining, as many companies are being privatized. The impact of most of the reforms are mainly diluted as state-owned enterprises are more tilted towards achieving social and political objectives set out by the governing regime.

The main reason for the existing conflict of interest in Chinese companies relates to their ownership structure, as most of the companies are family-owned and thus, they have the power to appoint the board of directors, who in turn are also family members [38]. Thus, the presence of non-executive directors to some degree ensures the protection of rights of other stakeholders along with minority shareholders as compared to other directors, as non-executive directors are independent [39]. Since 2001, it became a paramount concern for regulatory authorities and thus, they incorporated many regulations including systems for the compulsory appointment of non-executive directors in every listed company, and clearly defined the duties and powers of these directors. Non-executive directors are required to voice their unbiased opinion and to protect the interests of all stakeholders, seeking to solve the issue of principal-agent conflicts. According to the rules set out by CSRC, the non-executive directors can only hold directorship in five companies at a time, and they are responsible for ensuring the protection of rights of key stakeholders such as minority shareholders, being required to form their independent opinion. Non-executive directors and female directors serve in monitoring and supervisory roles [40,41]. Their effectiveness can be judged from the reputational incentives [32].

Fama [3] relates the reputational incentives of non-executive directors as an addition to human capital and also states that it opens a door for further appointments of non-executive directors [3]. The main reward of Non-executive directors is not the monitoring of benefits, but rather, the main reward takes the form of enhancement of their reputation. Thus, their main concern lies within maintaining and enhancing their reputation, which increases opportunities for further employment [42]. Mobbs [22] also stresses that the incentive of a good reputation motivates these directors to carry out their jobs fully and effectively. So, the reputational incentives in turn also improve the corporate and 
social performance of the organization. Our arguments in favor of reputational incentives for Chinese non-executive directors are based upon these studies, and we also analyze the impact of non-executive directors' reputational incentive on CSR reporting.

The literature related to CSR in developing countries is very limited, and our research aims to bridge this gap by focusing on the CSR practices in the Chinese context, as China is the second-largest economy and largest developing economy in the world. Over time, China is experiencing rapid climate changes as well as societal changes in general, which in turn mean that companies need to modify their business practices and focus more on CSR related issues. This research will also add to the existing literature on the topic, in which researchers have mainly focused on developed economies such as the USA, Australia, and Europe.

\section{Theoretical Background, Literature Review, and Research Hypotheses}

\subsection{Theoretical Background}

Many theories tend to explain the motivation behind the disclosure of CSR activities by firms, such as stakeholder theory, which tends to relate such disclosures to the requirements of information by stakeholders [43]. The legitimacy theory relates such disclosures to efforts by firms to legitimize their actions towards shareholders and other stakeholders [44]. On the other hand, agency theory holds that agents disclose such information because of incentives they can draw from such activities [45]. Barako and Brown [46] state that the most prominent theory in this regard is the agency theory, as this theory links different factors of corporate governance and voluntary disclosure [47]. Assuming this, $\mathrm{Li}$ and Zheng [48] also present similar arguments for agency theory; our theories are also grounded by the use of this theory.

The two main agency issues highlighted by [16] hold that, first and foremost, it is related to the separation of ownership and management, so that owners are not managing the business. Thus, this leads to the second issue: Variation in the interests of both. According to Barako and Brown [46], the managers of a business tend to solve the issues of asymmetry in information in two ways: (i) By effective monitoring; and (ii) increasing the levels of disclosure. Sial and Chunmei [35] point out that the main duty of the board is to make sure that the personal interest of the managers does not overshadow the interests of shareholders. Researchers have argued that the effectiveness of the board of directors depends upon its characteristics, such as the size of the firm, gender diversity, and ratio of non-executive directors. Bassett and Koh [49] state that to follow the agency theory, the larger board will tend to perform well, as it will have a larger pool of expertise, opinion, and more deliberation on decisions as compared to a smaller one. The non-executive directors are expected to be more accountable, as they are considered to be unbiased or independent. Hence, the level of disclosure has to be higher [43]. The agency issues can be reduced by the inclusion of board gender diversity and non-executive directors [21], as they strike a crucial balance between the performance of the firm and the protection of the rights of stakeholders.

Many advantages are drawn by managers by voluntary disclosure, such as a reduction in agency information asymmetry, mitigation of agency issues, and dissemination of vital information to stakeholders about the business and social activities [49]. Barako and Brown [43] state that this also provides legitimacy to the decision of management. Such actions also suggest that resources are being utilized in an optimum way [49], which usually leads to a positive impression of the firm and helps in the lowering of financial costs for firms [50].

The agency conflicts also have a cost associated with all corporate actions, which can easily be eliminated by the active participation of females and independents on the board of directors [21]. Michelon and Parbonetti [11] have suggested that the agency conflicts can easily be reduced by board gender diversity and non-executive directors, as they tend to be neutral and watch out for all shareholders, rather than work for a specific group. They also state that an agency theory centered approach dictates that such actions also improve the transparency of corporate decision making 
and reputation of the company with different stakeholders as well. Thus, the level of asymmetric information is reduced by voluntary reporting of CSR activities. The active gender-diverse board and non-executive directors tend to align to the overall objectives of the managers, i.e., overall wealth increase which will lead to an increase of the wealth of shareholders. The CSR activities also bring the non-shareholding stakeholder on board as well, since they benefit from such activities. With an increase in the number of female directors and non-executive directors, the monitoring aspect also increases, which leads to an increase in CSR activities and their disclosure as well [21].

\subsection{Literature Review and Research Hypotheses}

\subsubsection{Gender Diversity and CSR Reporting}

Female board members would generate various alternatives to organizational strategies and procedures based on their different points of view, which has a positive impact on the decision making process and decision making outcomes of the board. According to Bear and Rahman [51], female directors also improve the implantation aspect of CSR decisions and policies. One such example is the increase in charitable contributions by companies with female board members, as noted by $[52,53]$. The companies with a higher number of female directors tend to have better CSR reporting [54-56]. At the same time, firms with higher charitable contributions also have a better environmental record [57]. Panwar and Han [58,59] state that the reason for the above-mentioned activities can mainly be attributed to a more demanding attitude of women towards CSR related activities, and they tend to be more scrutinizing as compared to their male counterparts, in the timber industry. They also serve as representatives of women stakeholders [60], and this improves the overall performance of the company, as the decision making incorporates diverse opinions and concerns along with a representation of different stakeholders. One of the messages that is sent out by firms with female directors is that they care about all the stakeholders such as women and minorities and thus can build a positive perception in the general public [51]. The female directors are a valuable addition to the human capital of every organizational setting [12].

According to Ali and Sial [61] and Sial and Zheng [62], the presence of females in boards of directors improves the overall effectiveness of corporate governance. The differences related to demography, including the gender of the $C E O$, is an important variable for gauging the effectiveness of monitoring activities of the Board [63], but there is no universal consensus of its impact on the CSR of the firms [64]. In this research, the authors argue in favor of the positive impact of gender diversity on CSR reporting.

The gender diversity adds to existing perspectives related to implementation, monitoring, and reporting of CSR activities, along with the fact that women in the board of directors also act as representatives of group stakeholders. The decision-making process is improved by the inclusion of female members in boards, as they provide the difference of opinion and diversity in decision making [65]. This diversity of opinions also promotes critical thinking aspects and improves the quality of decisions regarding the strategies and their implementations [66]. Research conducted by Fernandez-Feijoo and Romero [67] states that including women on the board of directors improves the CSR and its reporting, along with enhancing the quality of decisions taken by the board in this regard.

Secondly, the presence of female board members also ensures prompt and agile implementation of CSR related decisions [51]. Companies which have female board members are more likely to engage in charitable activities [68]. The research has also proved that the presence of female directors improves the charitable contributions [54]. At the same time, the companies which engage in charity are more likely to have higher levels of social and environmental activities [57,69]. Panwar and Han [58] hold that female directors are more vigilant and stricter when it comes to issues relating to CSR and environment, and besides, they also act as representatives of the female population as well [51,70]. The inclusion of female directors also embodies the representativeness of women stakeholders in society. This improves the firm's acceptability amongst minorities, and their social profile also improves, as shown in the 
social acceptability of businesses [51]. To sum up the debate, it can be safely said that female directors are a valuable part of human capital and their presence also improves decision making [12].

It is also argued that gender diversity at a higher level of corporations puts a significant effect on its overall performance, as female board members are found to be very committed, diligent, and get involved themselves [71]. So, it is overall argued that diversity of gender could impact the level of CSR and environmental reporting positively. Some recent studies also found the same results [72-74]. Therefore, we followed the above-mentioned studies and developed our first hypothesis:

Hypothesis 1. Gender diversity in board of directors positively affects CSR reporting.

\subsubsection{Non-Executive Directors' Reputational Incentives and CSR Reporting}

Jensen and Meckling [75] state that the main objective of the board of directors is to monitor the managers on behalf of shareholders, and they occupy a supervisory role in the context of agency theory. They look after the interests of shareholders and other stakeholders in decision making. The whole process of corporate governance is influenced by the composition and demographic qualities of board members. Jo and Harjoto [76] state that one way of gauging the transparency of this process is to analyses social practices and the disclosure of social activities by companies.

The independence of the board can be gauged by the fact that board members are not dependent upon the company in respect to salaries, privileges, or other monetary incentives. In other words, they are not relying on the company to provide them with financial and non-financial incentives [77]. According to Jensen and Meckling [75], the agency theory dictates that managers, including the board of directors, always have incentives to influence the financial performance of the company, as their financial incentives are tied to financial performance. Meanwhile, non-executive directors are more interested in forcing companies to comply with laws and regulations [78]. They tend to enforce ethical considerations on behalf of the owners of the company (shareholders). This discourages unethical behavior between the managers, and also promotes better monitoring of the financial performance [21]. This not only discourages unethical issues such as fraud, but also improves the overall performance of the companies [79]. They improve existing relationships between management and other stakeholders. This results in improvemenst and sustainability in the financial and non-financial aspects of a firm's performance.

The presence of a positive relationship between the performance of the company and the presence of non-executive directors is well documented [80]. Meanwhile, Jamali [81] adds that their presence also improves voluntary disclosures such as CSR. Their presence also improves the quality of audits, as they are more willing to spend higher amounts towards large audit firms to further the credibility of the financial statements issued by companies [82], which discourages management from manipulating financial results. In the case of China, one of the main mechanisms in this respect is the supervisory board. According to the Code of Corporate Governance issued by CSRC, the supervisory board scrutinizes the financial performance of the company by analyzing the financial statements and overseeing the accounting system. To summarize the discussion, it can be deduced that the presence of non-executive directors not only improves corporate social activities, but also improves the decision making and credibility of a company's financial statements. The improvement in quality of audits discourages accounting manipulations and reduces opportunities for frauds, thus boosting the confidence of shareholders and other stakeholders in the company. Drawing from the above discussion, we anticipate that the level of CSR activities will increase with the increase in the number of non-executive directors on the board of directors.

Reputation is considered as one of the most valuable assets by non-executive directors [83], which has a positive impact on their future in the labor market, as it portrays them in a positive light in terms of character, integrity, and skills [23]. This serves as the main motivation for non-executive directors, as indicated by [31], who advocated that reputational incentive is the main motivation for non-executive directors to perform their duties, and it also has a great influence on their corporate 
behavior [31]. According to Mobbs [22], this also influences their attendance in board meetings, their behavior (such as attention to details), and supervisory function. A person with a higher reputation is more eager to enhance their reputation by working hard and performing their duties more diligently.

In the case of China, the main duties of directors include protection of the rights of minority shareholders and other stakeholders, and the presence of non-executive directors ensures this function is performed effectively. Based upon this, we present our second hypothesis:

Hypothesis 2. Non-executive directors' reputational incentives improve the CSR reporting.

\subsubsection{Moderating Effect of Firm Size}

Non-executive directors with a high reputation are more likely to devote time and effort to effectively perform their functions and improve the CSR reporting of organizations. But at the same time, they hold directorship positions, which limit their ability to effectively perform their duties due to a lack of time [84]. Directors have faced this dilemma, which in turn is related to the fact of reputational incentives of non-executive directors, which are affected by the limitation of time. So, these directors mostly fail to give equal time to their commitments, and allocation of time and effort is usually based on the contribution of the organization towards enhancing their reputation. In China, large organizations offer non-executive directors positions based upon their reputation, which opens the door for these non-executive directors to seek permanent directorship in these organizations. So, they are more likely to invest their time in larger organizations. Sial and Chunmei [85] found that non-executive directors holding multiple positions often tended to have better attendance records at the larger organizations as compared to the smaller ones [31]. Thus, non-executive directors at larger firms are more likely to work harder, as a reputational incentive from these firms is greater. We focus on firm size considering that this feature can play a moderating effect on the relationship between board gender diversity and CSR reporting because more creative boards are associated with more diversity in their structures, have improved board's decision-making skills, and make problem-solving more effective, especially regarding the complex one [17].

Academic literature has reported that CSR is positively associated with firm size. McGuinness [26] stated that large corporations tend to be more attuned to social actions than small firms. For these authors, large firms tend to have a stronger social impact through their scale of activities. Rossi [56] adds by saying that large corporations have more visibility and then are highly motivated to align their business with stakeholders' expectations, including firms' social engagements. On the other hand, large firms are more exposed, so that intense public attention may push those firms to have more socially respectful activities [44]. Therefore, we propose that a firm's size will be positively associated with its social performance, moderating the relationship between board gender diversity and CSR reporting. Although firm size is considered as a key factor in firm's activities and management, previous studies only include it as one of the control variables in analyzing the relationship between gender diversity and firm CSR reporting [65]. In this paper, we are interested in whether firm size similarly plays the moderating role in enhancing the impact of board gender diversity on firm CSR reporting. Based on the above discussion, we present our third and fourth hypothesis.

Hypothesis 3. Firm size moderates the relationship between non-executive directors' reputational incentives and CSR reporting.

Hypothesis 4. Firm size moderates the relationship between gender diversity in board of directors and CSR reporting. 


\section{Methodology}

\subsection{Sample and Data}

Our data was collected from the Chinese companies registered with the Shanghai stock exchange from the 2009-2019 time period. The 4029 firm-year observations have been taken into consideration for investigating the developed hypotheses. We used panel data by considering data over time and across companies. CSR data was provided by two sources, namely the database of CSMAR and the RKS rating independent agency. The CSMAR database provides in-depth information about the financial aspects of Chinese companies, information which also includes the composition of the board, the number of directors, and the financial performance of companies [86]. Meanwhile, the RKS rating agency leads in providing information regarding to the CSR activities of Chinese firms, in line with the Global Reporting Initiative (3.0), and it has been considered one of the most credible sources of such information in past studies as well $[87,88]$. We restricted our sample to all non-financial companies. This selection process resulted in a final sample of 4029 unbalanced firm-year observations, shown in Table 1 , as follows.

Table 1. Sample description.

\begin{tabular}{cccc}
\hline Industry & Code & Observations & Percentage \\
\hline Agriculture & $\mathrm{A}$ & 121 & 3.00 \\
Mining and Dressing & $\mathrm{B}$ & 183 & 4.54 \\
Manufacturing & $\mathrm{C}$ & 2100 & 52.12 \\
Electric power and Supplies & $\mathrm{D}$ & 207 & 5.13 \\
Engineering Construction & $\mathrm{E}$ & 129 & 3.20 \\
Wholesale and Retail & $\mathrm{F}$ & 201 & 4.98 \\
Transportation & $\mathrm{G}$ & 234 & 5.80 \\
I.T & $\mathrm{I}$ & 165 & 4.09 \\
Real Estate & $\mathrm{K}$ & 261 & 6.47 \\
Business Services & $\mathrm{L}$ & 102 & 2.53 \\
Public Facilities Management & $\mathrm{N}$ & 101 & 2.50 \\
Journalism and Publication & $\mathrm{R}$ & 105 & 2.60 \\
Conglomerate & $\mathrm{S}$ & 120 & 2.97 \\
Total & & $\mathbf{4 0 2 9}$ & $\mathbf{1 0 0}$ \\
\hline
\end{tabular}

\subsection{Selection of Model}

We test our hypotheses by running a data panel regression analysis, to establish and validate the type and magnitude of relationships existing between the dependent and independent variables. The appropriateness of the model was tested via the Hausman test. The results indicated that the $p$-value was less than $0.001,(p<0.001)$, leading us to adopt a fixed effect model for further analysis.

\subsection{Measuring CSR Reporting}

The reliability of our CSR measure is acceptable, based on previous research of [54], who validated the measure by conducting the robustness check. The CSR reporting information was obtained from the RKS rating agency. The RKS Rating agency leads in providing information regarding the CSR activities of Chinese firms, in line with the Global Reporting Initiative (3.0), and it has been considered as one of the most credible sources of such information in past studies as well $[87,88]$. The range of the CSR rating is from zero to a hundred. We mainly focus on the independent variables: (i) The non-executive directors' reputational incentives; and (ii) the number of women serving as directors on boards of directors, representing the board gender diversity. 


\subsection{Measuring Board Gender Diversity and Non-Executive Directors Reputational Incentives}

The gender diversity in the board is measured by the Shannon index (1948), and boards with high female presence will display a high degree of homogeneity. To properly account for the number of gender categories (male and female) and for the evenness of the distribution of board members, we have used the Shannon index. The Shannon index is maximized when the proportion of men and women are maximized, so a Shannon index is considered as a comprehensive measure of gender diversity and measured as $\sum_{i=1}^{n} P_{i} \ln P_{i}$, where $P_{i}$ is the percent of male and female in the board and $\mathrm{n}$ is 2 , showing categories of male and female. The index can have a minimum value of 0 , and diversity is maximized when both genders are present in equal proportions, which gives rise to a value of 0.69. Non-executive directors' incentives (NEDI) are measured by taking the average number of directorships held by each non-executive director in a firm; so, for these variables data is obtained from the CSMAR database.

\subsection{Moderating Variable (Firm Size)}

We take the firm size as a moderator variable between non-executive directors' reputational incentives and CSR reporting. We measure the firm size by taking the natural log of total assets.

\subsection{Control Variables}

Some variables can influence CSR reporting, as discussed in the theoretical background. In this regard, we have use some corporate governance variables (female CEO, foreign institutional investor, board size, CEO power, board member meeting frequency, board member average age, board member average tenure, state-owned enterprises, firm age, leverage, big 4 , and return on assets) as control variables [89].

\subsection{The Model and Method}

Following Simnett and Vanstraelen [90], we have used the following regressions models to study the influence of both board gender diversity and non-executive directors' reputational incentives on CSR reporting.

$$
\begin{aligned}
& \left.\operatorname{CSRR}_{i t}=\beta_{0}+\beta_{1} \text { Gender Diversity (Shannon Index }\right)_{i t}+\beta_{2} \text { Female CEO }_{i t}+\beta_{3} \text { ForeignII }_{i t} \\
& +\beta_{4} \text { CEO Power } \text { Po }_{i t} \beta_{5} \text { BoardMMF }_{i t}+\beta_{6} \text { Board MAA }_{i t}+\beta_{7} \text { Board MAT }_{i t}+\beta_{8} S O E_{i t} \\
& +\beta_{9} \text { Firm Age }_{i t}+\beta_{10} \text { Firm Size }_{i t}+\beta_{11} \operatorname{Lev}_{i t}+\beta_{12} \text { Big4 }_{i t}+\beta_{13} \text { ROA }_{i t}+\varepsilon_{i t}
\end{aligned}
$$

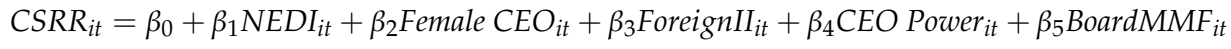

$$
\begin{aligned}
& +\beta_{6} \text { Board } M A A_{i t}+\beta_{7} \text { Board MAT } T_{i t}+\beta_{8} S O E_{i t}+\beta_{9} \text { Firm Age } e_{i t}+\beta_{10} \text { Firm Size }_{i t} \\
& +\beta_{11} \text { Lev }_{i t}+\beta_{12} \text { Big }_{i t}+\beta_{13} R O A_{i t}+\varepsilon_{i t}
\end{aligned}
$$

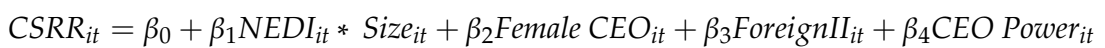

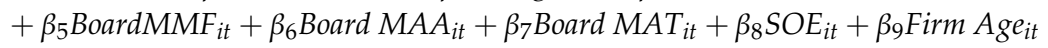

$$
\begin{aligned}
& +\beta_{10} \text { Firm Size }_{i t}+\beta_{11} \text { Lev }_{i t}+\beta_{12} \text { Big }_{i t}+\beta_{13} R O A_{i t}+\varepsilon_{i t} \\
& \operatorname{CSRR}_{i t}=\beta_{0}+\beta_{1} \text { Shannon Index }_{i t} * \text { Size }_{i t}+\beta_{2} \text { NEDI }_{i t}+\beta_{3} \text { Female CEO }_{i t}+\beta_{4} \text { ForeignII }_{\text {it }} \\
& +\beta_{5} \text { CEO Power } \text { Pit }+\beta_{6} \text { BoardMMF }_{i t}+\beta_{7} \text { Board MAA } A_{i t}+\beta_{8} \text { Board MAT }_{i t} \\
& +\beta_{9} S O E_{i t}+\beta_{10} \text { Firm Age }_{i t}+\beta_{11} \text { Firm Size }_{i t}+\beta_{12} \operatorname{Lev}_{i t}+\beta_{13} \text { Big }_{i t}+\beta_{14} R O A_{i t}+\varepsilon_{i t}
\end{aligned}
$$

where, the dependent variable is CSR reporting (CSRR) measured by using the rating score of the RKS agency. Gender diversity in the board of directors is measured by (Shannon_Index) (1948), which is considered as a comprehensive measure of gender diversity and measured by using the following formula- $\sum_{i=1}^{n} P_{i} \ln P_{i}$. Where: $P_{i}$ is a percent of male and female in the board and $n$ is 2 , showing categories of male and female; non-executive directors incentives (NEDI), measured by taking the average number of directorships held by each non-executive director in the firm; female chief executive officer (Female_CEO, measured by considering the dummy variable if female CEO exist 
in the board then 1, otherwise equal to 0); foreign institutional investors (Foreign_II, measured by taking percentage of foreign institutional investors in the board); board size (Board_S, is total number of directors in the board); chief executive power (CEO_P, if the chairman and CEO are the same then equal to one, otherwise zero); board member meeting frequency (Board_MMF, measured by total number of meetings in one year); board member average age (Board_MAA, measured by average age of board members); board member average tenure (Board_MAT, measured by average tenure of the board members); state owned enterprises (SOE, if firm is government controlled then equal to one, otherwise equal to zero); firm age (Firm_A, measured by total number of firm listing years); firm size (Firm_Size, measured by $\mathrm{n}$ log of total assets); leverage (Lev, measured by total debt divided by total assets); big 4 (Big4, if firm audited their reports from big 4 then equal to one, otherwise equal to zero); return on assets (ROA, measured by net income divided by total assets).

\section{Empirical Results}

\subsection{Descriptive Statistics}

The descriptive statistics are presented in Table 2. The average CSR reporting is 0.4746 with a standard deviation of 0.1158 . The mean value of gender diversity in board proxy (Shannon_Index) is 0.1335 , with a standard deviation of 0.0582 . It means that female directors are $13 \%$, on average, in Chinese companies, below the US and UK listed firms, but higher than in other developing countries, such as Brazil, Chile, and Mexico.

Table 2. Descriptive statistics.

\begin{tabular}{cccc}
\hline Variable & Obs & Mean & Std. Dev \\
\hline CSR reporting (CSRR) & 4029 & 0.4746 & 0.1158 \\
Gender Diversity Shannon Index & 4029 & 0.092 & 0.0582 \\
Gender Diversity (\%) & 4029 & 0.1335 & 0.0582 \\
Non-executive Directors' Incentives (NEDI) & 4029 & 03.019 & 1.4561 \\
Female_CEO & 4029 & 0.0643 & 0.0247 \\
Foreign_II & 4029 & 14.384 & 0.0350 \\
Board_Size & 4029 & 9.5448 & 2.3091 \\
CEO_Power & 4029 & 0.1698 & 0.0383 \\
Board_MMF & 4029 & 8.9487 & 2.4410 \\
Board_MAA & 4029 & 52.873 & 3.8165 \\
Board_MAT & 4029 & 3.6086 & 1.3132 \\
Firm_Age & 4029 & 0.5899 & 0.0498 \\
Firm_Size & 4029 & 10.989 & 4.6254 \\
Lev & 4029 & 22.056 & 1.7543 \\
Big4 & 4029 & 0.5067 & 0.2165 \\
State Owned Enterprises (SOE) & 4029 & 0.1689 & 0.0715 \\
Return On Assets (ROA) & 4029 & 0.0586 & 0.03901 \\
\hline
\end{tabular}

The average value of non-executive directors is 3.019 with a standard deviation of 1.4561 . The mean value of firm size is found to be 22. The average found for return on assets is 0.0586 with a standard deviation of 0.03901 .

The sample consists of Chinese companies from 2009 to 2019. The dependent variable is CSR reporting (CSRR) measured by using the rating score of the RKS agency. Gender diversity in the board of directors is measured by (Shannon_Index) (1948), which is considered as a comprehensive measure of gender diversity and measured by using formula- $\sum_{i=1}^{n} P_{i} \ln P_{i}$. Where: $P_{i}$ is a percent of male and female in the board and $n$ is 2, showing categories of male and female; non-executive directors incentives (NEDI), measured by taking the average number of directorships held by each non-executive director in firm; female chief executive officer (Female_CEO, measured by considering the dummy variable if a female CEO exists in the board then 1, otherwise equal to 0); foreign institutional investors (Foreign_II, measured by taking percentage of foreign institutional investors in the board); board size (Board_S, 
is total number of directors in the board); chief executive power (CEO_P, if chairman and CEO are the same then equal to one, otherwise zero); board member meeting frequency (Board_MMF, measured by total number of meetings in one year); board member average age (Board_MAA, measured by average age of board members); board member average tenure (Board_MAT, measured by average tenure of the board members); state owned enterprises (SOE, if firm is government controlled then equal to one, otherwise equal to zero); firm age (Firm_A, measured by total number of firm listing years); firm size (Firm_Size, measured by $\mathrm{n} \log$ of total assets); leverage (Lev, measured by total debt divided by total assets); big 4 (Big4, if firm audited their reports from big 4 then it is equal to one, otherwise equal to zero); return on assets (ROA, measured by net income divided by total assets).

\subsection{Correlation Matrix}

Table 3 represents the Correlation matrix of all variables used in the study. The maximum pairwise correlation is between board size and firm size (0.4456). Hence, there is no multicollinearity problem. Table 3 also suggests that there is no multicollinearity problem in the data that can affect the results. Further, the variance inflation factor(VIF) is under the limit of 3 , and the value is less than 0.60 of the correlation between all variables under consideration, which is under the maximum level.

\subsection{Results and Discussion}

Table 4 shows the results of the fixed-effect regression analysis of variables tested in our study: Board gender diversity and reputational incentives of non-executive directors on CSR reporting. Model 1 reports the regression results for testing H1. Our findings suggests that gender diversity in the board (Shannon Index) in model $1(\beta=0.3958, p<0.05)$ is positively related to CSR reporting. Model 2 reports the regression results for testing $\mathrm{H} 2$, and our results also suggest that reputational incentives of non-executive directors is significant and has a positive effect on CSR reporting $(\beta=0.9261, p<0.05)$. Our results declare that gender diversity in the board is statistically significant with CSR reporting. Moreover, the results are also totally aligned with [72,73], who found the same association between gender diversity at the senior level and CSR reporting. 
Table 3. Correlation matrix.

\begin{tabular}{|c|c|c|c|c|c|c|c|c|c|c|c|c|c|c|c|c|c|}
\hline . & 1 & 2 & 3 & 4 & 5 & 6 & 7 & 8 & 9 & 10 & 11 & 12 & 13 & 14 & 15 & 16 & VIF \\
\hline 1-CSRR & 1.0000 & & & & & & & & & & & & & & & & \\
\hline 2-Shannon_I & $0.0533 * * *$ & 1.0000 & & & & & & & & & & & & & & & 1.07 \\
\hline 3-NEDI & 0.0056 & $0.0277^{*}$ & 1.0000 & & & & & & & & & & & & & & 1.13 \\
\hline 4-Female_CEO & 0.0056 & $0.1554^{* * *}$ & -0.0186 & 1.0000 & & & & & & & & & & & & & 1.03 \\
\hline 5-Foreign_II & 0.0182 & -0.0027 & $-0.0270 *$ & $0.0353 * *$ & 1.0000 & & & & & & & & & & & & 1.07 \\
\hline 6-Board_Size & 0.0306 ** & $0.0872 * * *$ & $-0.2468 * * *$ & -0.0279 ** & $0.1117^{* * *}$ & 1.0000 & & & & & & & & & & & 1.47 \\
\hline 7-CEO_Power & -0.0077 & $0.0517^{* * *}$ & $0.0867^{* * *}$ & -0.0048 & -0.0209 & $-0.1416 * * *$ & 1.0000 & & & & & & & & & & 1.09 \\
\hline 8-Board_MMF & $-0.0406 * * *$ & $0.0640^{* * *}$ & $0.0428 * * *$ & $0.0277^{*}$ & $-0.0672 * * *$ & 0.0235 & $-0.0127^{* * *}$ & 1.0000 & & & & & & & & & 1.09 \\
\hline 9-Board_MAA & 0.0224 & $-0.0719 * * *$ & $0.0778^{* * *}$ & $-0.0623 * * *$ & 0.0159 & $0.0628^{* * *}$ & $-0.0650^{* * *}$ & $-0.0359 * *$ & 1.0000 & & & & & & & & 1.14 \\
\hline 10-Board_MAT & $0.0348 * *$ & $0.0314^{* *}$ & 0.0129 & 0.0158 & -0.0031 & $-0.0103 * * *$ & $0.0606 * * *$ & $-0.0308 * *$ & $0.1515 * * *$ & 1.0000 & & & & & & & 1.08 \\
\hline 11-SOE & 0.0141 & $-0.1183 * * *$ & $-0.0291 * *$ & $-0.1043 * * *$ & 0.0873 *** & $0.1937^{* * * *}$ & $-0.2309 * * *$ & $-0.0722 * * *$ & 0.1535 *** & $-0.0870 * * *$ & 1.0000 & & & & & & 1.30 \\
\hline 12-Firm_Age & -0.0022 & 0.0172 & -0.0142 & -0.0105 & 0.0691 *** & $0.0409 * * *$ & $-0.1278^{* * *}$ & $0.0616^{* * * *}$ & $0.2057^{* * *}$ & $0.1181^{* * * *}$ & $0.3133^{* * * *}$ & 1.0000 & & & & & 1.25 \\
\hline 13-Firm_Size & $0.0402 * * *$ & -0.0198 & $0.0541^{* * *}$ & -0.0175 & $0.1562^{* * * *}$ & 0.4456 **** & $-0.1328 * * *$ & $0.1704^{* * *}$ & $0.2014^{* * *}$ & $0.0079^{* * *}$ & $0.2912^{* * *}$ & $0.1894^{* * *}$ & 1.0000 & & & & 2.63 \\
\hline 14-Lev & $0.0438 * * *$ & -0.0346 ** & 0.0179 & 0.0009 & $0.0343 * *$ & $0.2577 * * *$ & $-0.1254^{* * * *}$ & $0.1920^{* * * *}$ & $0.0737^{* * *}$ & $-0.0862^{* * * *}$ & $0.2129^{* * * *}$ & $0.2620^{* * * *}$ & $0.5959 * * *$ & 1.0000 & & & 1.90 \\
\hline 15-Big4 & 0.0509 & $-0.0425 * * *$ & $0.0538^{* * *}$ & 0.0103 & $0.1780^{* * *}$ & $0.2649 * * *$ & $-0.0799 * * * *$ & $0.0612 * * *$ & $0.0724^{* * *}$ & -0.0020 & $0.1674^{* * *}$ & $0.0298 * *$ & $0.5468 * * *$ & $0.2277^{* * * *}$ & 1.0000 & & 1.49 \\
\hline 16-ROA & 0.0063 & 0.0227 & 0.0021 & $0.0538 * * *$ & $0.0637 * * *$ & $-0.0979 * * *$ & $0.0951^{* * * *}$ & $-0.0895 * * *$ & $-0.1229 * * *$ & 0.0091 & $-0.1468^{* * * *}$ & $-0.1595 * * *$ & $-0.1699 * * *$ & $-0.3678^{* * *}$ & $-0.0432 *$ & 1.0000 & 1.20 \\
\hline
\end{tabular}


Table 4. Do board gender diversity and reputational incentives of non-executive directors (NEDs) affect CSRR?

\begin{tabular}{|c|c|c|c|c|}
\hline \multirow{2}{*}{ Variables } & \multicolumn{2}{|c|}{ Model 1 (CSRR) } & \multicolumn{2}{|c|}{ Model 2 (CRRR) } \\
\hline & Coef. & $p$-Value & Coef & $p$-Value \\
\hline Gender Diversity (Shannon Index) & $0.3958^{* *}$ & 0.025 & - & - \\
\hline NEDI & - & - & $0.9261^{* *}$ & 0.049 \\
\hline Female_CEO & 0.2395 & 0.597 & $0.3960 * *$ & 0.387 \\
\hline Foreign_II & 0.1896 & 0.587 & 0.1718 & 0.622 \\
\hline Board_Size & 0.0144 * & 0.051 & 0.0259 * & 0.067 \\
\hline CEO_Power & 0.0604 & 0.833 & 0.0630 & 0.826 \\
\hline Board_MMF & 0.0219 & 0.369 & 0.0191 & 0.432 \\
\hline Board_MAA & 0.0389 & 0.181 & 0.0346 & 0.238 \\
\hline Board_MAT & $0.3332 * * *$ & 0.000 & $0.3236^{* * *}$ & 0.000 \\
\hline SOEE & -0.3709 & 0.143 & -0.3990 & 0.116 \\
\hline Firm_Age & 0.0061 & 0.771 & 0.0027 & 0.898 \\
\hline Firm_Size & $0.1469^{* *}$ & 0.023 & $0.1395^{* *}$ & 0.027 \\
\hline Lev & $2.544^{* * *}$ & 0.001 & $2.489^{* * *}$ & 0.001 \\
\hline Big4 & $1.041^{* *}$ & 0.042 & $1.014^{* *}$ & 0.048 \\
\hline ROA & $4.035 * *$ & 0.050 & $3.918^{* *}$ & 0.056 \\
\hline No of Obs & \multicolumn{2}{|c|}{4029} & \multicolumn{2}{|c|}{4029} \\
\hline $\mathrm{R}^{2}$ & \multicolumn{2}{|c|}{$21.03 \%$} & \multicolumn{2}{|c|}{$21.58 \%$} \\
\hline
\end{tabular}

Note: ${ }^{* * *},{ }^{* *}$, and ${ }^{*}$ represent $p<0.01, p<0.05, p<0.1$. The sample consists of Chinese companies from 2009 to 2019. The dependent variable is CSR reporting (CSRR) measured by using the rating score of RKS rating agency. Gender diversity in a board is measured by (Shannon_Index) (1948), which is considered a comprehensive measure of gender diversity and measured by using formula- $\sum_{i=1}^{n} P_{i} \ln P_{i}$. Where: $P_{i}$ is percent of male and female in the board and $n$ is 2, showing categories of male and female; non-executive directors incentives (NEDI), measured by taking the average number of directorships held by each non-executive director in firm; female chief executive officer (Female_CEO, measured by considering the dummy variable if female a CEO exists in the board then 1, otherwise equal to 0); foreign institutional investors (Foreign_II, measured by taking percentage of foreign institutional investors in the board); board size (Board_S, total number of directors in the board); chief executive power (CEO_P, if chairman and CEO are the same then equal to one, otherwise zero); board member meeting frequency (Board_MMF, measured by total number of meetings in one year); board member average age (Board_MAA, measured by average age of board members); board member average tenure (Board_MAT, measured by average tenure of board members); state owned enterprises (SOE, if firm is government controlled then equal to one, otherwise equal to zero); firm age (Firm_Age, measured by total number of firm listing years); firm size (Firm_Size, measured by $n$ log of total assets); leverage (Lev, measured by total debt divided by total assets); big 4 (Big4, if firm audited their reports from big 4 then equal to one, otherwise equal to zero); return on assets (ROA, measured by net income divided by total assets).

The extent of CSR disclosure is deeply affected by the presence of women on the board in a positive manner. Williams [52] states the reason for this as female directors tend to be more sensitive towards social activities. Ibrahim and Angelidis [91] state that it is more likely that successful firms hire more female directors, and thus they're able to invest more in such social activities, as they can afford to so. Williams [52] also held similar findings, followed by Bear and Rahman [51], and Meng and Zeng [92], and they both cite that the presence of female directors has a positive impact on CSR disclosure. Javaid Lone and Ali [93] held that the presence of non-executive directors has a positive impact on firms and promotes higher levels of CSR related disclosures. The reputational incentives of non-executive directors have a positive impact on CSR reporting in model 2. Non-executive directors not only protect and promote the rights of shareholders, but also of other stakeholders. Agency theory advocates that the presence of non-executive directors increases the CSR disclosure. The presence of non-executive directors also ensures not only a reduction in agency cost resulting from agency conflicts, but also enhances the quality of disclosure via effective monitoring. Such activities lead to a better quality of management and reduce the chances of opportunistic behavior of managers [94-96].

The moderating effect of the firm size mentioned in Table 5 and results indicate that the firm size positively moderates the relationship between reputational incentives of non-executive directors and CSR reporting in model $1(\beta=0.0761, p<0.05)$. Our findings show that firm size strengthens the effect of reputational incentives of the non-executive directors' on CSR, supporting our hypothesis 
H3. This lends support to the earlier discussion, which indicated that reputational incentives of non-executive directors are affected by the allocation of time, which indicated that non-executive directors allocate more time and energy to large firms due to better reputation and future opportunities. Our findings also show that the firm size positively moderates the relationship between gender diversity in the board and CSR reporting in model $2(\beta=0.0456, p<0.05)$, supporting our hypothesis H4. It means big firms are more socially responsible with CSR reporting as compared to smaller firms because big firms are associated with slack-financial resources as compared to smaller firms, and this significantly affects CSR reporting [93].

Table 5. The moderating role of firm size on gender diversity of the board of directors and reputational incentives of non-executive directors with CSRR.

\begin{tabular}{|c|c|c|c|c|}
\hline \multirow{2}{*}{ Variables } & \multicolumn{2}{|c|}{ Model 1 (CSRR) } & \multicolumn{2}{|c|}{ Model 2 (CSRR) } \\
\hline & Coef & $p$-Value & Coef. & $p$-Value \\
\hline NEDI*Size & $0.0761^{* *}$ & 0.023 & \multicolumn{2}{|c|}{ 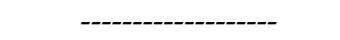 } \\
\hline Shannon_Index*Size & ------- & ---- & $0.0456^{* *}$ & 0.051 \\
\hline NEDI & $0.6014^{* *}$ & 0.032 & $0.6126^{* *}$ & 0.034 \\
\hline Gender Diversity (Shannon_Index) & $0.3267 * *$ & 0.042 & $0.3688^{* *}$ & 0.028 \\
\hline Female_CEO & $0.2260 * *$ & 0.387 & 0.2295 & 0.453 \\
\hline Foreign_II & 0.1718 & 0.622 & 0.9618 & 0.728 \\
\hline Board_S & 0.0159 * & 0.067 & 0.0143 * & 0.061 \\
\hline CEO_P & 0.0730 & 0.826 & 0.07243 & 0.335 \\
\hline Board_MMF & 0.0190 & 0.432 & 0.01054 & 0.961 \\
\hline Board_MAA & 0.0349 & 0.238 & 0.0389 & 0.183 \\
\hline Board_MAT & $0.3266^{* * *}$ & 0.000 & $0.3354^{* * *}$ & 0.000 \\
\hline SOE & -0.3790 & 0.116 & -0.3865 & 0.344 \\
\hline Firm_A & 0.0047 & 0.898 & 0.0054 & 0.165 \\
\hline Firm_Size & $0.1315^{* *}$ & 0.027 & $0.1154^{* *}$ & 0.015 \\
\hline Lev & $2.689 * * *$ & 0.001 & $2.513^{* * *}$ & 0.003 \\
\hline Big_4 & $1.014^{* *}$ & 0.048 & $1.016^{* *}$ & 0.025 \\
\hline $\mathrm{ROA}$ & $3.918^{* *}$ & 0.056 & $4.020^{* *}$ & 0.050 \\
\hline No of Obs & \multicolumn{2}{|c|}{4029} & \multicolumn{2}{|c|}{4029} \\
\hline $\mathrm{R}^{2}$ & \multicolumn{2}{|c|}{$21.28 \%$} & \multicolumn{2}{|c|}{$20.76 \%$} \\
\hline
\end{tabular}

Note: ${ }^{* * *}, * *$, and ${ }^{*}$ represent $p<0.01, p<0.05, p<0.1$. The sample consists of Chinese companies from 2009 to 2019. The dependent variable is CSR reporting (CSRR) measured by using the rating score of the RKS rating agency. Gender diversity in the board is measured by (Shannon_Index) (1948), which is considered a comprehensive measure of gender diversity and measured by using formula- $\sum_{i=1}^{n} P_{i} \ln P_{i}$. Where: $P_{i}$ is the percentage of male and female in the board and $n$ is 2, showing categories of male and female; non-executive directors incentives (NEDI), measured by taking the average number of directorships held by each non-executive director in firm; female chief executive officer (Female_CEO, measured by considering the dummy variable if a female CEO exists in the board then 1, otherwise equal to 0); foreign institutional investors (Foreign_II, measured by taking percentage of foreign institutional investors in the board); board size (Board_S, total number of directors in the board); chief executive power (CEO_P, if the chairman and CEO are the same then equal to one, otherwise zero); board member meeting frequency (Board_MMF, measured by total number of meetings in one year); Board member average age (Board_MAA, measured by average age of board members); board member average tenure (Board_MAT, measured by average tenure of board members); state owned enterprises (SOE, if firm is government controlled then equal to one, otherwise equal to zero); firm age (Firm_Age, measured by total number of firm listing years); firm size (Firm_Size, measured by $n$ log of total assets); leverage (Lev, measured by total debt divided by total assets); big 4 (Big4, if firm audited their reports from big 4 then equal to one, otherwise equal to zero); return on assets (ROA, measured by net income divided by total assets).

Regarding control variables, the board's size has a direct and significant relationship $(p=0.051)$ with CSR reporting. It also clearly indicates that larger boards have more probability of providing higher CSR disclosures than smaller boards and are consistent with the results found by other prior studies like [89,97-99]. Board member, average tenure, leverage, big 4, and return on assets also significantly related to CSR reporting. 


\subsection{Discussion of Results}

Our findings add to the literature by explaining how board gender diversity improves firm CSR reporting. These findings are also very crucial due to the empirical support provided about the favorable effects of the board gender diversity on corporations' CSR reporting. As already mentioned above, despite the general thought that gender diversity in the board of directors enhances CSR reporting. Hence, by empirically analyzing and taking a large sample for testing this relationship, our study makes an important addition to the literature. Our findings are very important for academia and officials at middle-level management, etc. to check the effect of board gender diversity and reputational incentives of non-executive directors on CSR reporting. In the case of academia, examining this association will improve the knowledge base of the impacts of gender diversity and reputational incentives of non-executive directors on CSR reporting. For managerial practitioners, the studying of gender diversity and reputational incentives of non-executives would help them in making better decisions and improve their corporations' performance, specifically related to CSR protection.

The existence of agency relationships can be traced to the loss of control in the form of management of the business by shareholders to managers. The agency theory tends to provide resolution of this conflict, and how organizations can control this conflict is the area of interest for most researchers. Fama and Jensen [21] state that one of the main functions of the board is to examine the decisions and reasons for such decisions within the organizational settings, and this allows them to undertake the monitoring role, which is the main function of the board [21]. The non-executive directors act as referees, who tend to provide their independent opinion on such activities. According to agency theory, the majority of the board of directors need non-executive directors to reduce the agency conflict. They also state that this reduces the agency cost associated with rash decision-making. Michelon and Parbonetti [11] state that non-executive directors are mainly responsible for enhancing transparency in decision making and reporting, which enables the board to protect the shareholders' interests. The information asymmetry is reduced by voluntary disclosures such as CSR reporting, helping to maintain and enhance the reputation of the reporting organization. Therefore, the level of CSR disclosure is a sign of an effective and efficient board, as it can align the interests of managers, shareholders, and other stakeholders.

The independence of the board is characterized by the presence of non-executive directors, because they ensure all the necessary check balances are in place [100] (Franks et al., 2001). Patelli and Prencipe [101] hold non-executive directors as a reliable mechanism for reducing agency conflicts and costs associated with such conflicts, and this also increases the supervisory aspects of the board along with improvements in the financial performance of the firms. Nowadays, they seem like a mechanism for accountability for managers as they ensure that managers not only look after the interests of shareholders, but that they also take into account the interests of other stakeholders [42]. Frias-Aceituno and Rodriguez-Ariza [102] state that the pressure of non-executive directors ensures that both the social impact of a firm's business activities and firm objectives are met, and thus this provides legitimacy to the actions of firms.

Non-executive directors have no financial or monetary dependence on the company. They are elected on the same notion, and they usually lack the in-depth knowledge of the business, as they are usually serving in similar capacity, i.e., director or equally responsible jobs. They can invest much of the time required, thus they cannot execute the responsibilities required by the supervisory role and they depend on the management to provide them with the information required for decision making, thus their effectiveness is compromised. One way of overcoming this issue can be that they regularly attend the board meetings to acquaint themselves with the affairs of the company. In this way, they will be in a better position to evaluate the information provided by the management and may be in a position to execute their supervisory role effectively. Another issue pointed out by Sartawi and Hindawi [103] relates to family or personal connections of non-executive directors with the management of the companies, which also compromises their effectiveness. In China, most businesses are government-owned and operated; in such cases, the state mostly operates as a unit and holds 
significant influence, and this is coupled with problems identified earlier, which explain the failure of non-executive directors to perform their supervisory role effectively. These examples also reiterate the principal-principal agency problems within the government-owned business. Such issues can easily be solved by the presence of an independent director, but only if they can effectively perform their duties. Even though such problems exist, still no one can deny the important role of non-executive directors in most industries, as this is also evident from the current study. In theory, our results lend support to agency theory, but only in part, while shedding light on the relationship between gender diversity and non-executive directors in the board of directors and CSR reporting.

\subsection{Robustness Test}

\subsubsection{Alternative Measure of Gender Diversity in Board}

To ensure the robustness of our findings, we have used the alternative measure of gender diversity in board proxies' proportion of female directors (PFD) in model 1, Blau Index (Blau_Index) in model 2 , and the female director dummy variable $(F D D)$ in model 3. The coefficient of PFD is positive and significant in model $1(\beta=1.002, p<0.05)$, coefficient of Blau_Index in model $2(\beta=1.040, p<0.05)$, and coefficient of $F D D$ in model $3(\beta=0.5804, p<0.05)$. Our results for the alternative measure of gender diversity in the board of directors are represented in Table 6 . These results are consistent with the main findings.

Table 6. Robustness test.

\begin{tabular}{|c|c|c|c|c|c|c|}
\hline \multirow{2}{*}{ Variables } & \multicolumn{2}{|c|}{ Model 1 (CSRR) } & \multicolumn{2}{|c|}{ Model 2 (CSRR) } & \multicolumn{2}{|c|}{ Model 3 (CSRR) } \\
\hline & Coef. & $p$-Value & Coef & $p$-Value & Coef & $p$-Value \\
\hline PFD & $1.002 * *$ & 0.0189 & - & 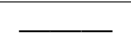 & - & 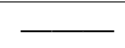 \\
\hline Gender Divrsity (Blau_Index) & & & $1.040 * *$ & 0.039 & & \\
\hline FDD & $\longrightarrow$ & - & - & & $0.5804^{* *}$ & 0.028 \\
\hline NED & $2.9981 *$ & 0.077 & $2.9891 *$ & 0.070 & $2.9514 *$ & 0.093 \\
\hline Female_CEO & 0.3540 & 0.444 & 0.4185 & 0.365 & 0.3682 & 0.420 \\
\hline Foreign_II & 0.1865 & 0.593 & 0.1724 & 0.622 & 0.1737 & 0.618 \\
\hline Board_S & 0.0122 & 0.843 & 0.0134 & 0.828 & 0.0306 & 0.623 \\
\hline CEO_P & 0.0810 & 0.777 & 0.0927 & 0.747 & 0.0495 & 0.863 \\
\hline Board_MMF & 0.0205 & 0.401 & 0.0200 & 0.412 & 0.0189 & 0.435 \\
\hline Board_MAA & 0.0360 & 0.220 & 0.0341 & 0.247 & 0.0354 & 0.227 \\
\hline Board_MAT & $0.3236^{* * *}$ & 0.000 & $0.3195^{* * *}$ & 0.001 & $0.3264^{* * *}$ & 0.000 \\
\hline SOEE & -0.3974 & 0.118 & -0.4057 & 0.110 & -0.3933 & 0.121 \\
\hline Firm_A & 0.0070 & 0.737 & 0.0055 & 0.792 & 0.0018 & 0.928 \\
\hline Firm_Size & 0.1389 & 0.259 & 0.1348 & 0.274 & 0.1424 & 0.246 \\
\hline Lev & $2.533^{* * *}$ & 0.001 & $2.521 * * *$ & 0.001 & $2.483^{* * *}$ & 0.001 \\
\hline Big_4 & $1.019^{* *}$ & 0.047 & $1.014^{* *}$ & 0.048 & $1.017^{* *}$ & 0.047 \\
\hline ROA & $4.004^{* *}$ & 0.052 & $3.992 * *$ & 0.052 & $3.899 * *$ & 0.057 \\
\hline No of Obs & \multicolumn{2}{|c|}{4029} & \multicolumn{2}{|c|}{4029} & \multicolumn{2}{|c|}{4029} \\
\hline $\mathrm{R}^{2}$ & \multicolumn{2}{|c|}{$21.20 \%$} & \multicolumn{2}{|c|}{$21.47 \%$} & \multicolumn{2}{|c|}{$21.56 \%$} \\
\hline
\end{tabular}

\footnotetext{
Note: ${ }^{* * *}, * *$, and ${ }^{*}$ represent $p<0.01, p<0.05, p<0.1$. The sample consists of Chinese companies from 2009 to 2019. The dependent variable is CSR reporting (CSRR) measured by using the rating score of the RKS rating agency. Gender diversity in the board is measured by the proportion of female directors (PFD, Blau_Index and female director dummy). Non-executive directors incentives (NEDI), measured by taking the average number of directorships held by each non-executive director in firm; female chief executive officer (Female_CEO, measured by considering the dummy variable if a female CEO exists in the board then 1 , otherwise equal to 0 ); foreign institutional investors (Foreign_II, measured by taking percentage of foreign institutional investors in the board); board size (Board_S, total number of directors in the board); chief executive power (CEO_P, if the chairman and CEO are the same then equal to one, otherwise zero); board member meeting frequency (Board_MMF, measured by total number of meetings in one year); board member average age (Board_MAA, measured by average age of board members); board member average tenure (Board_MAT, measured by average tenure of board members); state owned enterprises (SOE, if the firm is government controlled then equal to one, otherwise equal to zero); firm age (Firm_Age, measured by total number of firm listing years); firm size (Firm_Size, measured by $n \log$ of total assets); leverage (Lev, measured by total debt divided by total assets); big 4 (Big4, if firm audited their reports from big 4 then equal to one, otherwise equal to zero); return on assets (ROA, measured by net income divided by total assets).
} 


\subsubsection{Controlling the Endogeneity Problem}

Additionally, to deal with the possibility of an endogeneity problem, we used the 2SLS regression model with instrument variable (lagged values of gender diversity and reputational incentives of non-executive directors, which are likely to meet the exclusion restriction); (i.e., correlated with board gender diversity and non-executive directors, and not correlated with CSR reporting). Table 7 represents the results of 2SLS regressions. The two-stage least square also validates our main findings.

Table 7. Two-stage least square (2SLS) regression.

\begin{tabular}{|c|c|c|c|c|}
\hline \multirow{2}{*}{ Variables } & \multicolumn{2}{|c|}{ Model 1 (CSRR) } & \multicolumn{2}{|c|}{ Model 2 (CRRR) } \\
\hline & Coef. & $p$-Value & Coef & $p$-Value \\
\hline Lagged Gender Diversity (Shannon_Index) & $0.3746^{* *}$ & 0.045 & - & - \\
\hline Lagged NEDI & - & - & $0.8261^{* *}$ & 0.041 \\
\hline Female_CEO & 0.2295 & 0.697 & $0.3460 * *$ & 0.287 \\
\hline Foreign_II & 0.1996 & 0.787 & 0.1918 & 0.612 \\
\hline Board_Size & $0.01164 *$ & 0.041 & 0.0239 * & 0.077 \\
\hline CEO_Power & 0.0608 & 0.733 & 0.0610 & 0.926 \\
\hline Board_MMF & 0.0218 & 0.219 & 0.0291 & 0.412 \\
\hline Board_MAA & 0.0489 & 0.161 & 0.0446 & 0.228 \\
\hline Board_MAT & $0.3232^{* * *}$ & 0.000 & $0.3036^{* * *}$ & 0.000 \\
\hline SOE & -0.3609 & 0.113 & -0.3590 & 0.216 \\
\hline Firm_Age & 0.0061 & 0.741 & 0.0057 & 0.798 \\
\hline Firm_Size & $0.1369 * *$ & 0.022 & $0.1295^{* *}$ & 0.025 \\
\hline Lev & $2.144^{* * *}$ & 0.001 & $2.689^{* * *}$ & 0.001 \\
\hline Big4 & $1.041 * *$ & 0.043 & $1.024^{* *}$ & 0.038 \\
\hline ROA & $3.035^{* *}$ & 0.040 & $3.818^{* *}$ & 0.046 \\
\hline No of Obs & \multicolumn{2}{|c|}{4029} & \multicolumn{2}{|c|}{4029} \\
\hline WaldCh$^{2}$ & \multicolumn{2}{|c|}{1234.46} & \multicolumn{2}{|c|}{1164.28} \\
\hline$R^{2}$ & \multicolumn{2}{|c|}{$18.018 \%$} & \multicolumn{2}{|c|}{$16.85 \%$} \\
\hline
\end{tabular}

Note: ${ }^{* * *}, * *$ and $*$ represent $p<0.01, p<0.05, p<0.1$. The sample consists of Chinese companies from 2009 to 2019. The dependent variable is CSR reporting (CSRR) measured by using the rating score of RKS rating agency. Gender diversity in the board is measured by (Shannon_Index) (1948), which is considered as comprehensive measure of gender diversity and measured by using formula- $\sum_{i=1}^{n} P_{i} \ln P_{i}$. Where: $P_{i}$ is percent of male and female in the board and $n$ is 2 , showing categories of male and female; non-executive directors incentives (NEDI), measured by taking the average number of directorships held by each non-executive director in firm; female chief executive officers (Female_CEO, measured by considering the dummy variable if a female CEO exists in the board then 1, otherwise equal to 0); foreign institutional investors (Foreign_II, measured by taking percentage of foreign institutional investors in the board); board size (Board_S, total number of directors in the board); chief executive power (CEO_P, if the chairman and CEO are the same then equal to one, otherwise zero); board member meeting frequency (Board_MMF, measured by total number of meetings in one year); board member average age (Board_MAA, measured by average age of board members); board member average tenure (Board_MAT, measured by average tenure of board members); state owned enterprises (SOE, if the firm is government controlled then equal to one, otherwise equal to zero); firm age (Firm_Age, measured by total number of firm listing years); firm size (Firm_Size, measured by $n$ log of total assets); leverage (Lev, measured by total debt divided by total assets); Big 4 (Big4, if the firm audited their reports from big 4 then equal to one, otherwise equal to zero); return on assets (ROA, measured by net income divided by total assets).

\section{Final Thoughts and Future Research}

The main aim of our study was to verify whether board gender diversity and reputational incentives of non-executive directors' affect CSR reporting. For this purpose, the effect of board gender diversity and reputational incentives of non-executive directors on CSR reporting of non-financial firms listed on the Shanghai Stock Exchange from 2009 to 2019 has been examined.

In this regard, we provide useful findings on the optimum balance of board gender diversity and reputational incentives of non-executive directors in the context of CSR reporting. The senior managers can better make themselves able to increase a corporations' performance with a more relevant knowledge base regarding the effects of diversity of gender of their higher-level workforce on organizations' environmental policy. In brief, diversity of gender as regards boards of directors can help to improve corporations' CSR related disclosures. The findings of this study lead to various useful summaries. First, for public listed corporations, the increasing diversity of gender may increase firms' CSR disclosures. As already mentioned in the discussion above, this may be due to various 
factors, which include a higher understanding of CSR at the firm level and personal characteristics of women at the management level.

Our findings also show that firm size moderates the relationship between board gender diversity and CSR reporting. This finding seems to be consistent with the view that CSR initiatives could be effective in larger companies due to their availability of financial resources, experience, and reputation. In contrast, smaller firms tend to use their financial resources to improve performance in their businesses through more traditional strategies, especially those financially constrained.

Second, the present research provides useful insight for policymakers and regulators alike regarding how they can enhance the effectiveness of gender diversity and non-executive directors in board of directors in respect to CSR reporting. The establishment of CSR rating and ranking can be used to prompt female and non-executive directors to fully execute their responsibilities. As a matter of fact, our results lend support to reputational incentives for female and non-executive directors, which prompts them to better understand and execute their role, resulting in improvements of CSR activities in the Chinese corporate sector.

Third, our findings also show that when we discuss how to motivate non-executive directors in CSR, it is necessary to consider the reputation mechanism. Our paper shows that reputational incentives have a strong influence on non-executive directors' behaviors and represent an important dimension of non-executive directors' incentives. For policymakers, this provides a basic framework to establish the reputation mechanism for the non-executive directors, so that they can perform their duties more efficiently. Our results also indicate that improvements in reputational incentives for non-executive directors will also lead to better CSR reporting of Chinese firms as regards large firms, and will also improve the CSR practices in China.

Fourth, the results of our study could also enrich the literature on business ethics, business strategy, and gender studies in firms. Finally, for trainers and educational practitioners of companies, our findings will help them understand the relationship between gender diversity and non-executive directors on the board of directors and CSR reporting. Furthermore, after becoming aware of this favorable effect of having more female members on the board of directors, companies will consider the idea of having female officials more seriously and work more cooperatively towards this end. This study will also definitely aid in improving firm CSR disclosures along with fulfilling CSR related requirements.

The main limitation of the research relates to the Chinese context of the study and the fact that the results cannot be generalized for other countries due to differences in corporate and social setups. In the future, researchers can conduct cross-sectional studies on similar topics.

Secondly, for future research, it is possible to extend the scope of our design by taking into account other factors, such as the duality of CEOs and behavioral aspects of management, at both firm and industry level, in order to extract comprehensive results, which can be generalized in similar cultural and socio-economic setups, such as East Asian countries. Moreover, the quality of CSR disclosures is still a rather raw area. Hence, further studies could be aimed at analyzing the impacts that the characteristics of boards of directors have upon the quality of CSR disclosures in Chinese background.

Author Contributions: Conceptualization, C.G., M.S.S., P.W., A.B., D.B., and T.V.B.; methodology, C.G., M.S.S., P.W., A.B., D.B., and T.V.B.; formal analysis, C.G., M.S.S., P.W., A.B., D.B., and T.V.B.; investigation, C.G., M.S.S., P.W., A.B., D.B., and T.V.B.; writing-original draft preparation, C.G., M.S.S., P.W., A.B., D.B., and T.V.B.; writing一review and editing, C.G., M.S.S., P.W., A.B., D.B., and T.V.B. All authors have read and agreed to the published version of the manuscript.

Funding: We would like to acknowledge the financial support from the Zhejiang Provincial Natural Science Foundation of China (Grant Numbers: LY20G020009) and the National Natural Science Foundation of China (Grant Numbers: 71502166).

Conflicts of Interest: The authors declare no conflict of interest. 


\section{References}

1. Mallouh, A.A.; Tahtamouni, A. The impact of social responsibility disclosure on the liquidity of the Jordanian industrial corporations. Int. J. Manag. Financ. Account. 2018, 10, 273-300. [CrossRef]

2. Kuo, L.; Yeh, C.C.; Yu, H.C. Disclosure of corporate social responsibility and environmental management: Evidence from China. Corp. Soc. Responsib. Environ. Manag. 2012, 19, 273-287. [CrossRef]

3. Fama, E.F. Agency Problems and the Theory of the Firm. J. Political Econ. 1980, 88, 288-307. [CrossRef]

4. Van Rekom, J.; Berens, G.; Van Halderen, M. Corporate social responsibility: Playing to win, or playing not to lose? Doing good by increasing the social benefits of a company's core activities. J. Brand Manag. 2013, 20, 800-814. [CrossRef]

5. Rossi, M.; Nerino, M.; Capasso, A. Corporate governance and financial performance of Italian listed firms. The results of an empirical research. Corp. Ownersh. Control. 2015, 12, 628-643. [CrossRef]

6. Widyaningsih, I.U.; Gunardi, A.; Rossi, M.; Rahmawati, R. Expropriation by the controlling shareholders on firm value in the context of Indonesia: Corporate governance as moderating variable. Int. J. Manag. Financ. Account. 2017, 9, 322-337. [CrossRef]

7. Robinson, G.; Dechant, K. Building a business case for diversity. Acad. Manag. Perspect. 1997, 11, 21-31. [CrossRef]

8. Eccles, G.R.; Ioannou, I.; Serafeim, G. The impact of corporate sustainability on organizational processes and performance. Manag. Sci. 2014, 60, 2835-2857. [CrossRef]

9. Cho, C.H.; Patten, D.M. The role of environmental disclosures as tools of legitimacy: A research note. Account. Organ. Soc. 2007, 32, 639-647. [CrossRef]

10. Patten, D.M. The relation between environmental performance and environmental disclosure: A research note. Account. Organ. Soc. 2002, 27, 763-773. [CrossRef]

11. Michelon, G.; Parbonetti, A. The effect of corporate governance on sustainability disclosure. J. Manag. Gov. 2012, 16, 477-509. [CrossRef]

12. Terjesen, S.; Couto, E.B.; Francisco, P.M. Does the presence of independent and female directors impact firm performance? A multi-country study of board diversity. J. Manag. Gov. 2016, 20, 447-483. [CrossRef]

13. Galbreath, J.; Shum, P. Do customer satisfaction and reputation mediate the CSR-FP link? Evidence from Australia. Aust. J. Manag. 2012, 37, 211-229. [CrossRef]

14. Fernández-Gago, R.; Cabeza-García, L.; Nieto, M. Corporate social responsibility, board of directors, and firm performance: An analysis of their relationships. Rev. Manag. Sci. 2016, 10, 85-104. [CrossRef]

15. Firth, M.; Wong, S.; Xin, Q.; Yick, H.Y. Regulatory sanctions on independent directors and their consequences to the director labor market: Evidence from China. J. Bus. Ethics 2016, 134, 693-708. [CrossRef]

16. Wang, Y.; Jin, P.; Yang, C. Relations between the professional backgrounds of independent directors in state-owned enterprises and corporate performance. Int. Rev. Econ. Financ. 2016, 42, 404-411. [CrossRef]

17. Chen, R.; Dyball, M.C.; Wright, S. The link between board composition and corporate diversification in Australian corporations. Corp. Gov. 2009, 17, 208-223. [CrossRef]

18. Chen, X.; Cheng, Q.; Wang, X. Does increased board independence reduce earnings management? Evidence from recent regulatory reforms. Rev. Account. Stud. 2015, 20, 899-933. [CrossRef]

19. Liu, H.; Wang, H.; Wu, L. Removing Vacant Chairs: Does Independent Directors' Attendance at Board Meetings Matter? J. Bus. Ethics 2016, 133, 375-393. [CrossRef]

20. Cavaco, S.; Crifo, P.; Rebérioux, A.; Roudaut, G. Independent directors: Less informed but better selected than affiliated board members? J. Corp. Financ. 2017, 43, 106-121. [CrossRef]

21. Fama, E.F.; Jensen, M.C. Separation of ownership and control. J. Law Econ. 1983, 26, 301-325. [CrossRef]

22. Mobbs, S. CEOs under fire: The effects of competition from inside directors on forced CEO turnover and CEO compensation. J. Financ. Quant. Anal. 2013, 48, 669-698. [CrossRef]

23. Brickley, A.J.; Linck, J.S.; Coles, J.L. What happens to CEOs after they retire? New evidence on career concerns, horizon problems, and CEO incentives. J. Financ. Econ. 1999, 52, 341-377. [CrossRef]

24. Ahn, S.; Jiraporn, P.; Kim, Y.S. Multiple directorships and acquirer returns. J. Bank. Financ. 2010, 34, $2011-2026$. [CrossRef]

25. Hasan, I.; Kobeissi, N.; Liu, L.; Wang, H. Corporate social responsibility and firm financial performance: The mediating role of productivity. J. Bus. Ethics 2018, 149, 671-688. [CrossRef]

26. McGuinness, B.P.; Vieito, J.P.; Wang, M. The role of board gender and foreign ownership in the CSR performance of Chinese listed firms. J. Corp. Financ. 2017, 42, 75-99. [CrossRef] 
27. Sena, V.; Duygun, M.; Lubrano, G.; Marra, M.; Shaban, M. Board independence, corruption and innovation. Some evidence on UK subsidiaries. J. Corp. Financ. 2018, 50, 22-43. [CrossRef]

28. Muller, A.; Kolk, A. Extrinsic and intrinsic drivers of corporate social performance: Evidence from foreign and domestic firms in Mexico. J. Manag. Stud. 2010, 47, 1-26. [CrossRef]

29. Cheng, L. Estimating the value of political connections in China: Evidence from sudden deaths of politically connected independent directors. J. Comp. Econ. 2018, 46, 495-514. [CrossRef]

30. Hussain, N.; Rigoni, U.; Orij, R.P. Corporate governance and sustainability performance: Analysis of triple bottom line performance. J. Bus. Ethics 2018, 149, 411-432. [CrossRef]

31. Sila, V.; Gonzalez, A.; Hagendorff, J. Independent director reputation incentives and stock price informativeness. J. Corp. Financ. 2017, 47, 219-235. [CrossRef]

32. Clarke, D.C. Corporate governance in China: An overview. China Econ. Rev. 2003, 14, 494-507. [CrossRef]

33. Dahya, J.; Karbhari, Y.; Xiao, J.Z.; Yang, M. The usefulness of the supervisory board report in China. Corp. Gov. Int. Rev. 2003, 11, 308-321. [CrossRef]

34. Chow, G.C. China's Economic Transformation; Wiley: Chichester, UK, 2015.

35. Firth, M.; Fung, P.M.; Rui, O.M. How ownership and corporate governance influence chief executive pay in China's listed firms. J. Bus. Res. 2007, 60, 776-785. [CrossRef]

36. Zhu, J.; Ye, K.; Tucker, J.W.; Chan, K.J.C. Board hierarchy, independent directors, and firm value: Evidence from China. J. Corp. Financ. 2016, 41, 262-279. [CrossRef]

37. DeFond, L.M.; Hann, R.N.; Hu, X. Does the market value financial expertise on audit committees of boards of directors? J. Account. Res. 2005, 43, 153-193. [CrossRef]

38. Zhou, F.; Fan, Y.; An, Y.; Zhong, L. Independent directors, non-controlling directors, and executive pay-for-performance sensitivity: Evidence from Chinese non-state owned enterprises. Pac.-Basin Financ. J. 2017, 43, 55-71. [CrossRef]

39. Li, W.; Krause, R.; Qin, X.; Zhang, J.; Zhu, H.; Lin, S.; Xu, Y. Under the microscope: A n experimental look at board transparency and director monitoring behavior. Strateg. Manag. J. 2018, 39, 1216-1236. [CrossRef]

40. Freeman, R.E. Strategic Management: A Stakeholder Approach; Cambridge University Press: New York, NY, USA, 2010.

41. Lindblom, C.K. The implications of organizational legitimacy for corporate social performance and disclosure. In Proceedings of the Critical Perspectives on Accounting Conference, New York, NY, USA, 16-18 April 1993.

42. Haniffa, R.M.; Cooke, T.E. The impact of culture and governance on corporate social reporting. J. Account. Public Policy 2005, 24, 391-430. [CrossRef]

43. Barako, D.G.; Brown, A.M. Corporate social reporting and board representation: Evidence from the Kenyan banking sector. J. Manag. Gov. 2008, 12, 309. [CrossRef]

44. Haat, C.M.H.; Rahman, R.A.; Mahenthiran, S. Corporate governance, transparency and performance of Malaysian companies. Manag. Audit. J. 2008, 23, 744-778. [CrossRef]

45. Li, X.; Zheng, C.; Liu, G.; Sial, M. The Effectiveness of Internal Control and Corporate Social Responsibility: Evidence from Chinese Capital Market. Sustainability 2018, 10, 4006. [CrossRef]

46. Van Riel, B.C.; Fombrun, C.J. Essentials of Corporate Communication: Implementing Practices for Effective Reputation Management; Routledge: Abingdon, UK, 2007.

47. Bassett, M.; Koh, P.-S.; Tutticci, I. The association between employee stock option disclosures and corporate governance: Evidence from an enhanced disclosure regime. Br. Account. Rev. 2007, 39, 303-322. [CrossRef]

48. Eng, L.L.; Mak, Y.T. Corporate governance and voluntary disclosure. J. Account. Public Policy 2003, $22,325-345$. [CrossRef]

49. Shehata, N.F. Theories and determinants of voluntary disclosure. Account. Financ. Res. 2014, 3. [CrossRef]

50. Lan, Y.; Wang, L.; Zhang, X. Determinants and features of voluntary disclosure in the Chinese stock market. China J. Account. Res. 2013, 6, 265-285. [CrossRef]

51. Bear, S.; Rahman, N.; Post, C. The impact of board diversity and gender composition on corporate social responsibility and firm reputation. J. Bus. Ethics 2010, 97, 207-221. [CrossRef]

52. Williams, R.J. Women on corporate boards of directors and their influence on corporate philanthropy. J. Bus. Ethics 2003, 42, 1-10. [CrossRef]

53. Li, Q.; Luo, W.; Wang, Y.; Wu, L. Firm performance, corporate ownership, and corporate social responsibility disclosure in China. Bus. Ethics 2013, 22, 159-173. [CrossRef] 
54. Marquis, C.; Qian, C. Corporate social responsibility reporting in China: Symbol or substance? Organ. Sci. 2013, 25, 127-148. [CrossRef]

55. Rossi, M.; Galasso, S.; Capasso, A. Women Do it Better: An Investigation on the Association between Gender Diversity in Board of Directors and the Financial Performance. Int. J. Econ. Financ. Issues 2017, 7, 41.

56. Shahab, Y.; Ye, C. Corporate social responsibility disclosure and corporate governance: Empirical insights on neo-institutional framework from China. Int. J. Discl. Gov. 2018, 15, 87-103. [CrossRef]

57. Post, C.; Rahman, N.; Rubow, E. Green governance: Boards of directors' composition and environmental corporate social responsibility. Bus. Soc. 2011, 50, 189-223. [CrossRef]

58. Panwar, R.; Han, X.; Hansen, E. A demographic examination of societal views regarding corporate social responsibility in the US forest products industry. For. Policy Econ. 2010, 12, 121-128. [CrossRef]

59. Wang, K.; Sewon, O.; Claiborne, M.C. Determinants and consequences of voluntary disclosure in an emerging market: Evidence from China. J. Int. Account. Audit. Tax. 2008, 17, 14-30. [CrossRef]

60. Lu, Y.; Abeysekera, I. Stakeholders' power, corporate characteristics, and social and environmental disclosure: Evidence from China. J. Clean. Prod. 2014, 64, 426-436. [CrossRef]

61. Ali, R.; Sial, M.S.; Brugni, T.V.; Hwang, J.; Khuong, N.V.; Khanh, T.H.T. Does CSR Moderate the Relationship between Corporate Governance and Chinese Firm's Financial Performance? Evidence from the Shanghai Stock Exchange (SSE) Firms. Sustainability 2020, 12, 149. [CrossRef]

62. Sial, M.; Zheng, C.; Cherian, J.; Gulzar, M.; Thu, P.; Khan, T.; Khuong, N. Does Corporate Social Responsibility Mediate the Relation between Boardroom Gender Diversity and Firm Performance of Chinese Listed Companies? Sustainability 2018, 10, 3591. [CrossRef]

63. Tsai, W.-H.; Hsu, J.-L. Corporate social responsibility programs choice and costs assessment in the airline industry-A hybrid model. J. Air Transp. Manag. 2008, 14, 188-196. [CrossRef]

64. Erhardt, L.N.; Werbel, J.D.; Shrader, C.B. Board of director diversity and firm financial performance. Corp. Gov. Int. Rev. 2003, 11, 102-111. [CrossRef]

65. Adams, C.A. A commentary on: Corporate social responsibility reporting and reputation risk management. Account. Audit. Account. J. 2008, 21, 365-370. [CrossRef]

66. Nielsen, S.; Huse, M. The contribution of women on boards of directors: Going beyond the surface. Corp. Gov. Int. Rev. 2010, 18, 136-148. [CrossRef]

67. Fernandez-Feijoo, B.; Romero, S.; Ruiz-Blanco, S. Women on boards: Do they affect sustainability reporting? Corp. Soc. Responsib. Environ. Manag. 2014, 21, 351-364. [CrossRef]

68. McWilliams, A.; Siegel, D. Corporate social responsibility and financial performance: Correlation or misspecification? Strateg. Manag. J. 2000, 21, 603-609. [CrossRef]

69. Sial, M.S.; Zheng, C.; Khuong, N.V.; Khan, T.; Usman, M. Does Firm Performance Influence Corporate Social Responsibility Reporting of Chinese Listed Companies? Sustainability 2018, 10, 2217. [CrossRef]

70. Chen, X.; Safdar Sial, M.; Tran, D.K.; Alhaddad, W.; Hwang, J.; Thu, P.A. Are Socially Responsible Companies Really Ethical? The Moderating Role of State-Owned Enterprises: Evidence from China. Sustainability 2020, 12, 2858. [CrossRef]

71. Sial, M.S.; Chunmei, Z.; Khan, T.; Nguyen, V.K. Corporate social responsibility, firm performance and the moderating effect of earnings management in Chinese firms. Asia-Pac. J. Bus. Adm. 2018, 10, 184-199. [CrossRef]

72. Rao, K.; Tilt, C. Board composition and corporate social responsibility: The role of diversity, gender, strategy and decision making. J. Bus. Ethics 2016, 138, 327-347. [CrossRef]

73. Rupley, H.K.; Brown, D.; Marshall, R.S. Governance, media and the quality of environmental disclosure. J. Account. Public Policy 2012, 31, 610-640. [CrossRef]

74. Cherian, J.; Safdar Sial, M.; Tran, D.K.; Hwang, J.; Khanh, T.H.T.; Ahmed, M. The Strength of CEOs' Influence on CSR in Chinese listed Companies. New Insights from an Agency Theory Perspective. Sustainability 2020, 12, 2190.

75. Jensen, M.C.; Meckling, W.H. Theory of the firm: Managerial behavior, agency costs and ownership structure. J. Financ. Econ. 1976, 3, 305-360. [CrossRef]

76. Jo, H.; Harjoto, M.A. Corporate governance and firm value: The impact of corporate social responsibility. J. Bus. Ethics 2011, 103, 351-383. [CrossRef]

77. Hillman, A.J.; Keim, G.D. Shareholder value, stakeholder management, and social issues: What's the bottom line? Strateg. Manag. J. 2001, 22, 125-139. [CrossRef] 
78. Ibrahim, N.A.; Angelidis, J.P. The corporate social responsiveness orientation of board members: Are there differences between inside and outside directors? J. Bus. Ethics 1995, 14, 405-410. [CrossRef]

79. Beasley, M.S. An empirical analysis of the relation between the board of director composition and financial statement fraud. Account. Rev. 1996, 71, 443-465.

80. O'Neill, M.H.; Saunders, C.B.; McCarthy, A.D. Board members, corporate social responsiveness and profitability: Are tradeoffs necessary? J. Bus. Ethics 1989, 8, 353-357. [CrossRef]

81. Jamali, D. A stakeholder approach to corporate social responsibility: A fresh perspective into theory and practice. J. Bus. Ethics 2008, 82, 213-231. [CrossRef]

82. Carcello, J.V.; Hermanson, D.R.; Neal, T.L.; Riley, R.A., Jr. Board characteristics and audit fees. Contemp. Account. Res. 2002, 19, 365-384. [CrossRef]

83. Ma, J.; Khanna, T. Independent directors' dissent on boards: Evidence from listed companies in China. Strateg. Manag. J. 2016, 37, 1547-1557. [CrossRef]

84. Zhang, D.; Ma, Q.; Morse, S. Motives for corporate social responsibility in Chinese food companies. Sustainability 2018, 10, 117. [CrossRef]

85. Sial, M.S.; Chunmei, Z.; Khuong, N.V. Do female and independent directors explain the two-way relationship between corporate social responsibility and earnings management of Chinese listed firms? Int. J. Account. Inf. Manag. 2019, 27, 442-460. [CrossRef]

86. Donnelly, R.; Mulcahy, M. Board structure, ownership, and voluntary disclosure in Ireland. Corp. Gov. 2008, 16, 416-429. [CrossRef]

87. Chen, X.; Wan, P. Social trust and corporate social responsibility: Evidence from China. Corp. Soc. Responsib. Environ. Manag. 2020, 27, 485-500. [CrossRef]

88. Chen, X.; Wan, P.; Quan, X.; Sial, M.S. Does corporate social responsibility matter to management forecast precision? Evidence from China. Econ. Res.-Ekon. Istraživanja 2020, 33, 1767-1795. [CrossRef]

89. Jizi, M.I.; Salama, A.; Dixon, R.; Stratling, R. Corporate governance and corporate social responsibility disclosure: Evidence from the US banking sector. J. Bus. Ethics 2014, 125, 601-615. [CrossRef]

90. Simnett, R.; Vanstraelen, A.; Chua, W.F. Assurance on sustainability reports: An international comparison. Account. Rev. 2009, 84, 937-967. [CrossRef]

91. Ibrahim, N.; Angelidis, J.; Tomic, I.M. Managers' attitudes toward codes of ethics: Are there gender differences? J. Bus. Ethics 2009, 90, 343-353. [CrossRef]

92. Meng, X.; Zeng, S.; Shi, J.J.; Qi, G.; Zhang, Z. The relationship between corporate environmental performance and environmental disclosure: An empirical study in China. J. Environ. Manag. 2014, 145, 357-367. [CrossRef]

93. Lone, E.J.; Ali, A.; Khan, I. Corporate governance and corporate social responsibility disclosure: Evidence from Pakistan. Corp. Gov. 2016, 16, 785-797. [CrossRef]

94. Cheng, E.C.; Courtenay, S.M. Board composition, regulatory regime and voluntary disclosure. Int. J. Account. 2006, 41, 262-289. [CrossRef]

95. Esa, E.; Ghazali, N.A.M. Corporate social responsibility and corporate governance in Malaysian government-linked companies. Corp. Gov. 2012, 12, 292-305. [CrossRef]

96. Liu, G.; Eng, T.-Y.; Ko, W.-W. Strategic direction of corporate community involvement. J. Bus. Ethics 2013, 115, 469-487. [CrossRef]

97. Ahmed Haji, A. Corporate social responsibility disclosures over time: Evidence from Malaysia. Manag. Audit. J. 2013, 28, 647-676. [CrossRef]

98. Liao, L.; Lin, T.P.; Zhang, Y. Corporate board and corporate social responsibility assurance: Evidence from China. J. Bus. Ethics 2016, 150, 211-225. [CrossRef]

99. Sun, L.; Al Farooque, O. An exploratory analysis of earnings management practices in Australia and New Zealand. Int. J. Account. Inf. Manag. 2018, 26, 81-114. [CrossRef]

100. Franks, J.; Mayer, C.; Renneboog, L. Who disciplines management in poorly performing companies? J. Financ. Intermediation 2001, 10, 209-248. [CrossRef]

101. Patelli, L.; Prencipe, A. The relationship between voluntary disclosure and independent directors in the presence of a dominant shareholder. Eur. Account. Rev. 2007, 16, 5-33. [CrossRef] 
102. Frias-Aceituno, V.J.; Rodriguez-Ariza, L.; Garcia-Sanchez, I.M. The role of the board in the dissemination of integrated corporate social reporting. Corp. Soc. Responsib. Environ. Manag. 2013, 20, 219-233. [CrossRef]

103. Sartawi, I.I.M.; Hindawi, R.M.; Bsoul, R. Board composition, firm characteristics, and voluntary disclosure: The case of Jordanian firms listed on the Amman stock exchange. Int. Bus. Res. 2014, 7, 67.

Publisher's Note: MDPI stays neutral with regard to jurisdictional claims in published maps and institutional affiliations.

(C) 2020 by the authors. Licensee MDPI, Basel, Switzerland. This article is an open access article distributed under the terms and conditions of the Creative Commons Attribution (CC BY) license (http://creativecommons.org/licenses/by/4.0/). 